\title{
ANÁLISE DO ÍNDICE DE VEGETAÇÃO POR DIFERENÇA NORMALIZADA NOS MUNICÍPIOS PRODUTORES DE PÓ DE CARNAÚBA NO PIAUÍ E CEARÁ
}

Emiliana Barros Cerqueira ${ }^{1}$ Jaíra Maria Alcobaça Gomes²

Resumo: Esse estudo analisa o Índice de Vegetação por Diferença Normalizada (NDVI) de municípios do Piauí e Ceará que extraem pó de carnaúba, comparando-o nos anos em que a precipitação pluviométrica foi semelhante e avalia as taxas de crescimento da atividade econômica e da população municipal. Para tanto, usou-se as imagens NDVI/MODIS disponíveis no site da Embrapa, dados sobre pluviometria, do Instituto Nacional de Pesquisas Espaciais e variáveis econômica e demográfica, do Censo Demográfico. As imagens desvelaram supressão de vegetação em algumas localidades decorrentes do aumento da urbanização ou da escala produtiva. Assim, é importante monitorar essas áreas para estabelecer políticas públicas adequadas para a conservação da vegetação nativa, considerando o risco de remoção de carnaúbas.

Palavras-chave: Carnaúba. NDVI. Supressão de vegetação. Urbanização. PIB.

\section{ANALYZES OF THE NORMALIZED DIFFERENCE VEGETATION INDEX IN THE MUNICIPAL PRODUCERS OF CARNAÚBA POWDER IN PIAUÍ AND CEARÁ}

Abstract: This study analyzes the Normalized Difference Vegetation Index (NDVI) of municipalities of Piauí and Ceará that extract carnauba dust, comparing it in the years in which the rainfall was similar and evaluates the growth rates of the economic activity and municipal population. For this purpose, the NDVI/MODIS images were used on the Embrapa website, pluviometry data, from National Institute for Space Research, ande economic and demographic variables, from Demographic Census. The images revealed suppression of vegetation in some localities, and this is due to the increase of the urbanization or the productive scale. Thus, it is important to monitor these areas to establish adequate public policies for the conservation of native vegetation, considering the risk of carnaúba removal.

Keywords: Carnauba. NDVI. Suppression of vegetation. Urbanization. GDP.

\section{ANÁLISIS DEL ÍNDICE DE VEGETACIÓN POR DIFERENCIA NORMALIZADA EN CIUDADES PRODUCTORAS DE POLVO DE CARNAUBA EN PIAUÍ Y CEARÁ}

Resumen: Este estudio analiza el Índice de Vegetación de Diferencia Normalizada (NDVI) de municipios de Piauí y Ceará que extraen polvo de carnauba, comparándolo en los años en que la lluvia fue similar y evalúa lo crecimiento de la actividad económica y población municipal. Para ello, se utilizaron las imágenes NDVI/MODIS disponibles en el sitio de Embrapa, datos sobre pluviometría, del Instituto Nacional de Investigación Espacial y variables económicas y demográficas, del Censo Demográfico. Las imágenes revelaron que hubo supresión de la vegetación en algunas localidades debido al aumento de la urbanización o la escala productiva. Así, es importante monitorear estas áreas para establecer políticas

\footnotetext{
1 Universidade Federal do Piauí, Programa de Pós-Graduação em Desenvolvimento e Meio Ambiente, Teresina, Brasil, emilianacerq@gmail.com, https://orcid.org/0000-0001-7084-3271 2 Universidade Federal do Piauí, Departamento de Ciências Econômicas, Teresina, Brasil, jaira@ufpi.edu.br, https://orcid.org/0000-0003-4664-9801
} 
públicas adecuadas para la conservación de la vegetación nativa, considerando el riesgo de remoción de carnauba.

Palabras clave: Carnauba. NDVI. Supresión de vegetación. Urbanización. PIB.

\section{Introdução}

A carnaúba (Copernicia prinifera (Mill.) H. E. Moore) é uma espécie nativa da região Nordeste do Brasil, ocorrendo principalmente nos Estados do Piauí e Ceará. Estes, juntos, produziram mais de 97\% do pó em 2011, segundo dados do Instituto Brasileiro de Geografia e Estatística - IBGE/Produção da Extração Vegetal e Silvicultura - PEVS (2011), ao passo que Rio Grande do Norte e Maranhão responderam pelo restante.

O principal produto extraído da carnaúba é o pó cerífero, do qual se obtém a cera, que possui inúmeras aplicações industriais, como nos ramos alimentícios, de polimentos e de medicamentos. No Piauí, a cera de carnaúba emergiu como um dos principais produtos da pauta de exportação. A partir de 2008, passou a ocupar a segunda posição no ranking, perdendo apenas para a soja. Em 2011, teve 26,83\% de participação no valor total de exportações piauienses, enquanto no Ceará, ficou na nona posição no ranking dos principais produtos exportados, com 4,15\% do valor total (MDIC/SECEX, 2011).

Tendo em vista a importância do mercado internacional para a economia dos países, Estados e municípios, a comercialização da cera de carnaúba pelo Piauí e Ceará, cuja produção é destinada quase totalmente ao exterior, denota a representatividade econômica desse segmento.

Ressalta-se, entretanto, que os carnaubais não contribuem apenas economicamente, uma vez que funcionam como símbolos de Estados, municípios e órgãos governamentais, e servem para a permanência da biodiversidade nos locais em que ocorrem, assumindo, então, valores sociais, culturais e ambientais.

Apesar dessa relevância, há supressões de carnaubais nativos, explicitadas por D'Alva (2007), ao mencionar a substituição deles, no Ceará, por perímetros de irrigação. Por sua vez, Cerqueira, Gomes e Silva (2011) relataram sua troca pela fruticultura, no Vale do Açu (RN).

Outro aspecto considerável é que os municípios produtores de pó de carnaúba no Piauí e Ceará estão inseridos no bioma caatinga. Este, consoante o MMA (2017), apesar de ter sua biodiversidade aproveitada por várias atividades 
econômicas ligadas, principalmente, aos ramos químico, farmacêutico e de cosméticos e alimentos, conta com um desmatamento que chega a $46 \%$ da área do bioma e se deve, sobretudo, ao consumo de lenha nativa, feita de modo insustentável e ilegal, ao sobrepastoreio e à conversão de florestas nativas em espaço para a agricultura e pastagens.

Reforçando essa assertiva, Queiroz, Rapini e Giulietti (2006) afirmaram que a caatinga é o bioma mais degradado do semiárido, com menos de $1 \%$ de sua área protegida por reservas. Assim sendo, a eliminação de vegetações nativas para dar lugar a outros usos da terra é uma prática comum, apesar das consequências que o desmatamento traz, como o aumento da temperatura, a perda de hábitats naturais e até mesmo a dizimação de espécies.

Young (2003) afirma que o desmatamento ocorre não porque os produtos ambientais não possuam importância econômica, mas devido à existência de outras formas de uso da terra, muitas vezes perpetuadas por políticas públicas que garantem recursos financeiros maiores ou mais rápidos. Esse imediatismo econômico tem consequências desastrosas no médio e longo prazo para a comunidade como um todo.

Dentre as alternativas para amenizar essa situação, podem-se elencar as convenções internacionais de proteção ao meio ambiente e a elaboração de políticas públicas ambientais. Além disso, existem mecanismos de monitoramento dos níveis de degradação, que permitem avaliar a quantidade e qualidade dos recursos naturais, a exemplo do Índice de Vegetação por Diferença Normalizada (NDVI), Índice de Vegetação Realçado (EVI), Índice de Vegetação do Solo Ajustado (SAVI). De acordo com o INPE (2017), o NDVI é o índice de vegetação mais comumente utilizado, e apresenta a vantagem de ser simples, não exigindo informações auxiliares adicionais.

Nesse contexto, objetiva-se analisar o índice de vegetação dos municípios do Piauí e Ceará que exploraram economicamente o pó cerífero de carnaúba no período de 2000 a 2011, e comparar os valores do NDVI nos anos em que a quantidade e distribuição de precipitação pluviométrica foram semelhantes, visando a apontar as áreas em que houve retirada de vegetação, com o intuito de alertar para a possibilidade de remoção dos carnaubais, além de avaliar as taxas de crescimento da escala produtiva e da densidade demográfica nesses locais. 


\section{Os usos do Índice de Vegetação por Diferença Normalizada}

Durante algum tempo, prevaleceu a ideia de inesgotabilidade dos recursos naturais e de resiliência do meio ambiente, isto é, capacidade de se autorrecuperar das agressões que Ihes eram causadas. A partir da década de 1970, vários debates internacionais foram realizados, por meio de conferências, objetivando alertar a humanidade sobre a necessidade de controlar os impactos do crescimento econômico e populacional sobre o meio ambiente.

De acordo com Oliveira (2012) a Conferência de Estocolmo, em 1972, foi a primeira delas, e teve como um de seus nortes o relatório publicado no mesmo ano pelo Clube de Roma, criado em 1968, intitulado "Limites do Crescimento", que pregava o crescimento zero. Outro relatório relevante, que suscitou discussões internacionais, foi publicado em 1992, "Nosso Futuro Comum" (Relatório Brundtland), resultando na Conferência das Nações Unidas sobre Meio Ambiente e Desenvolvimento, documento segundo o qual o crescimento é possível, desde que respeite os limites do planeta.

Desse modo, a degradação ambiental constitui uma preocupação, pois como há um limite até o qual se pode chegar, deve-se monitorar as áreas degradadas para posterior elaboração ou melhoramento de políticas em defesa do ecossistema natural. À vista disso, o NDVI revela-se como uma ferramenta essencial, pois conforme o INPE (2017), o índice possibilita mapear e medir a condição e quantidade de vegetação em determinada área, sendo útil em atividades como: análises do ciclo de crescimento vegetacional ou perturbações no ciclo sazonal; modelagem hidrológica e climática; detecção de desmatamentos e queimadas; monitoramento de secas; modelagem e produtividade de plantações agrícolas; percepção de mudanças climáticas; e estimativas de parâmetros da vegetação, como índice de área foliar e cobertura vegetal.

Cabe informar que esse índice foi proposto por Rouse et al. (1974), ao sugerir a normalização, para o intervalo de -1 a 1 , do Índice de Vegetação da Razão Simples, que foi inventado por Jordan (1960) e consistia na razão entre as bandas do infravermelho próximo e vermelho.

No levantamento bibliográfico realizado, foram encontrados trabalhos usando 
- NDVI para verificar modificações na cobertura vegetal, identificando desmatamentos, a exemplo dos de Melo, Sales e Oliveira (2011), Aquino e Oliveira (2012); e desertificação, como o de Andrade, Feitosa e Barbosa (2007). Outrossim, constataram-se estudos relacionando o NDVI a variáveis climáticas, como os desenvolvidos por Freire e Pacheco (2005), Lopes et al. (2010), Zhaoping, et al. (2011), Li et al. (2011) e Duan et al. (2011). Hong et al. (2010) correlacionaram o NDVI à umidade do solo. Santos e Shimabukuro (1993), Kazmierczak (1996), e Braga et al. (2003) apuraram a sazonalidade do índice. Lucas e Schuler (2007), e Junges \& Fontana (2009) examinaram o ciclo de crescimento da vegetação. Cardozo et al. (2011) avaliaram as áreas queimadas. Gurgel, Ferreira e Luiz (2003) apuraram a variabilidade anual e interanual do índice, correlacionando-as à precipitação.

Melo, Sales e Oliveira (2011) usaram o NDVI para identificar a cobertura vegetal na microbacia Riacho dos Cavalos (CE), associando seus valores aos tipos de vegetação, e constataram que houve redução significativa das áreas conservadas e expansão de atividades agropecuárias. Por sua vez, Aquino e Oliveira (2012) verificaram a dinâmica do NDVI no Núcleo de São Raimundo Nonato (PI), entre 1987 e 2007, com imagens Landsat 5 e 7, sensor TM. No geral, os resultados apontaram para uma melhoria nos níveis de proteção ambiental, com diminuição da degradação.

Andrade, Feitosa e Barbosa (2007) ancoraram-se no NDVI, a partir de imagens do sensor TM Landsat 7, em 2001, para identificar as áreas desertificadas em Serra Branca (PB), e complementaram a análise e interpretação do índice por meio de trabalho de campo. Seus estudos evidenciaram a vulnerabilidade a desastres ambientais no município, resultantes, principalmente, da ação antrópica.

Outro tipo de metodologia bastante desenvolvida equivale a comparar o índice de vegetação com precipitação e temperatura observadas em determinada área, já que essas variáveis modificam a vegetação e afetam os resultados do índice. Freire e Pacheco (2005) utilizaram o índice de vegetação para mapear as áreas de risco suscetíveis à desertificação na região do Xingó, entre 1978 e 2003, além de dados sobre as médias mensais pluviométricas, já que a resposta espectral da caatinga possui grande variabilidade com a presença de chuvas.

Foram identificados outros trabalhos relacionando o NDVI a índices de 
precipitação, como o de Lopes et al. (2010), onde apreciaram a importância de parâmetros biofísicos, como NDVI, albedo e temperatura da superfície, usando imagens TM Landsat 5 para a quantificação das mudanças no uso e cobertura do solo na Bacia do Rio Brígida (PE), entre 1985 e 2001. Os autores concluíram que o NDVI sofre maior influência da precipitação que a temperatura da superfície.

Zhaoping et al. (2011) estudaram as mudanças espaço-temporal do NDVI e sua relação com variáveis climáticas (temperatura e precipitação), no período de 1998 a 2007, na região da margem dos rios Yangtze e Yellow, na China, usando imagens do SPOT, sensor VEGETATION. Concluíram que o NDVI apresentou correlação positiva com a temperatura e precipitação.

Li et al. (2011) averiguaram os padrões espaciais de ligação entre o NDVI e variáveis climáticas na China, entre 1998 e 2008. Constataram que a relação entre NDVI e as variáveis analisadas difere segundo a região: ao Norte da China, o NDVI apresentou maior relação com a temperatura; nas áreas semiáridas e semiúmidas, com a precipitação.

Duan et al. (2011) aferiram mudanças temporais e espaciais do NDVI, correlacionando-as com temperatura e precipitação ao norte da China, de 1982 a 2006. Chegaram à conclusão de que o NDVI possui maior correlação com a precipitação que com a temperatura, mostrando-se mais elevado em 2006.

Hong et al. (2010) pesquisaram a correlação espacial e temporal entre o NDVI nos períodos com altos e baixos valores, e umidade do solo, de 2000 a 2006, no nordeste e na parte do sul da Coréia. Os resultados indicaram que durante o período em que o NDVI foi alto, houve uma relação inversa entre as duas variáveis analisadas, e quando foi baixo, ocorreu uma relação direta e ainda mais forte do que a conferida no período com altos índices de vegetação. Isso indica que o referido índice pode ser um bom indicador para conhecer a umidade do solo e identificar os períodos de seca.

A comparação em uma mesma data de análise, em anos diferentes, faz-se, pois, relevante, uma vez que o NDVI apresenta variações sazonais. Santos e Shimabukuro (1993), e Kazmierczak (1996), que estudaram, respectivamente, a região do cerrado e da caatinga, detectaram que o índice decresce quando há passagem de momentos com excesso para os de déficit hídrico, tornando mais perceptíveis as mudanças na variação do índice no período seco. 
Braga et al. (2003) estudaram a variabilidade sazonal do NDVI, identificando os fatores comuns temporais mensais do índice, usando análise fatorial no Nordeste brasileiro, entre agosto de 1981 e junho de 1991. Notaram que a sazonalidade está diretamente relacionada às alterações meteorológicas da região.

Lucas e Schuler (2007) sondaram o ciclo de crescimento da cultura de canade-açúcar associado à precipitação pluvial da safra de 2003/04, na Usina São José, município de Igarassu (PE), correlacionando-os ao NDVI. Averiguaram que o ciclo acompanha a variação do índice, embora não seja possível distinguir diferenças fenológicas no início (primeiro e segundo mês), tendo o valor máximo para o índice ocorrido no mês anterior ao corte.

A análise de monitoramento do crescimento da vegetação também foi realizada por Junges \& Fontana (2009), com a elaboração de perfis temporais de NDVI/MODIS para a construção de máscaras de cultivo, deslindando as variações interanuais dos perfis associadas ao rendimento de grãos de trigo no Rio Grande do Sul, relativas ao período de maio a novembro de 2000 a 2006. Comprovaram que os maiores rendimentos estão relacionados a elevados valores de NDVI. Sendo assim, perfis temporais do supracitado índice podem ser empregados para acompanhamento e previsão de safras.

Logo, o NDVI também é adotado para inspecionar o crescimento de plantações, destacando-se como uma ferramenta útil e precisa. Ademais, com ela é possível avistar a supressão da vegetação, como a ocasionada por queimadas.

A avaliação de áreas queimadas, promovida por Cardozo et al. (2011), utilizando o NDVI e o Índice de Queimada Normalizada (NDBR), na cidade de Brasília, entre junho e setembro de 2010, consistiu no cálculo das variações sofridas pelos dois índices nos momentos anteriores e posteriores às queimadas, bem como na medição da área total de extensão abrangida pela queimada. Em relação aos dois índices, captaram que o NDBR distinguiu melhor as áreas queimadas, tanto no que diz respeito à ocorrência quanto à severidade.

Gurgel, Ferreira e Luiz (2003) estabeleceram uma análise por agrupamentos, a partir dos valores do NDVI, abrangendo todo o Brasil, que foi dividido em nove grupos (análise de agrupamento), denotando que há variabilidade anual e interanual, e o tempo de resposta à precipitação das várias manchas de vegetação no país, nas regiões com períodos quentes e chuvosos marcantes têm ciclo anual bem 
caracterizado e resposta rápida à ocorrência de chuvas. Destarte, o El niño afeta distintamente os diversos tipos de vegetação, independentemente de sua intensidade, e o NDVI das regiões com vegetação mais verde e densa o ano todo sofrem maior variabilidade quando de anomalias climáticas.

À vista disso, assevera-se que o NDVI é um índice usado para os mais variados fins, a exemplo de identificar a cobertura vegetacional, analisar seu ciclo de crescimento e possibilitar a definição de áreas susceptíveis à desertificação, permitindo inferir afirmações acerca das modificações na cobertura vegetal de determinada área.

\section{Metodologia}

Esse artigo é parte integrante de uma pesquisa desenvolvida em 2014, cuja análise abrange o período de 2000 a 2011. A escolha desse recorte temporal justifica-se pela base de dados censitária disponibilizada pelo Instituto Brasileiro de Geografia e Estatística (IBGE), referente a 2000 e 2010. Incluiu-se o ano de 2011 devido ao fato de a metodologia empregada pelo NDVI requerer o comparativo de anos quando a quantidade e a distribuição de chuvas forem semelhantes.

A área de estudo compreende os municípios do Piauí e Ceará que exploram economicamente a carnaúba. Para delimitação desse espaço, empreendeu-se uma pesquisa no Sistema IBGE de Recuperação Automática (SIDRA), referente à Produção da Extração Vegetal e Silvicultura (PEVS), englobando o ínterim de 2000 a 2011, a fim de descobrir quem realizou atividade de extração do pó de carnaúba em todos os anos desse intervalo de tempo, definindo-se a área de estudo, ilustrada no Mapa 01, composta por 97 municípios no Estado do Piauí e 56 no Ceará. 
Mapa 01 - Municípios do Piauí e Ceará onde ocorre extração do pó de carnaúba

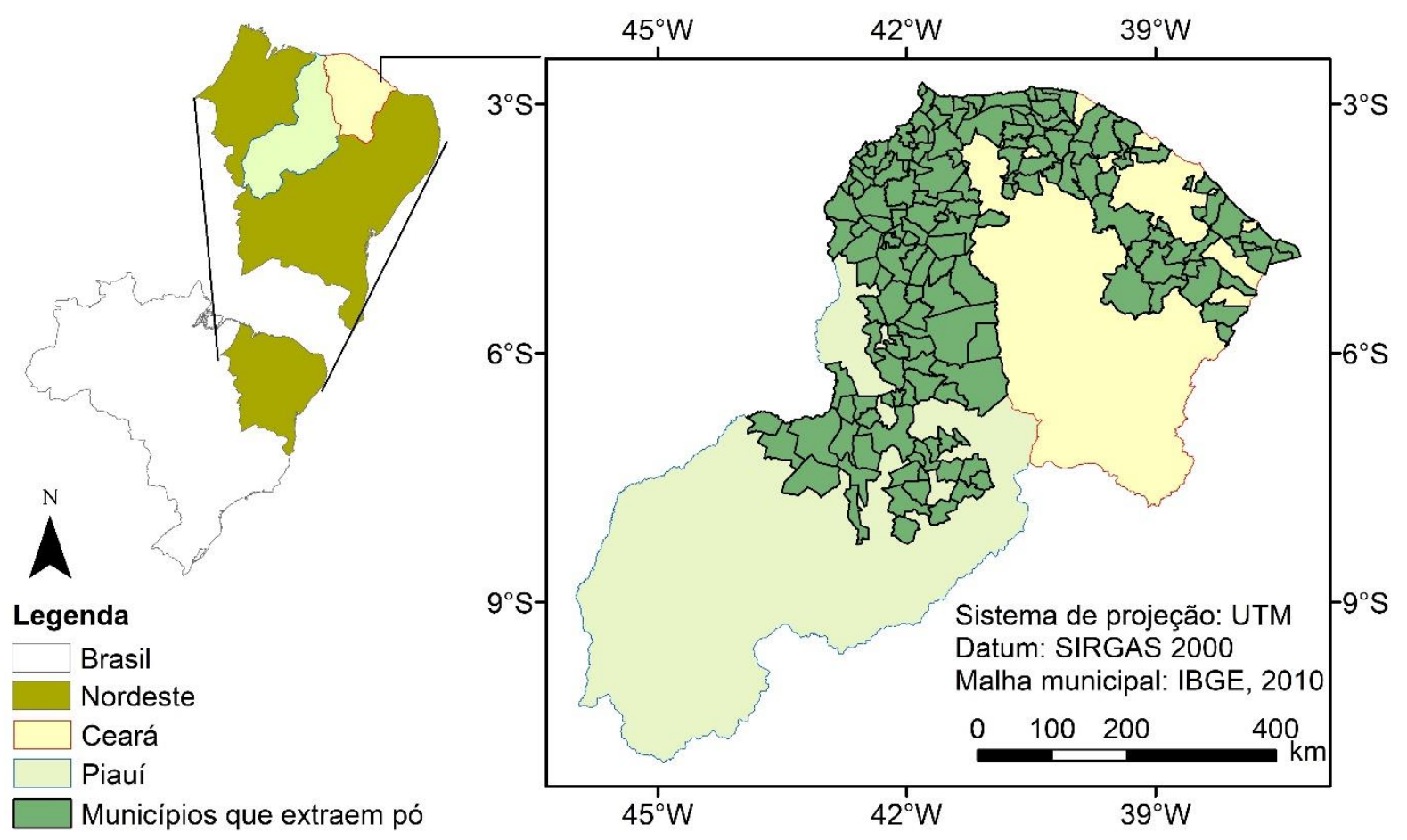

Fonte: Elaboração - Emiliana Barros Cerqueira. Dados básicos IBGE.

À título de curiosidade, Reis Filho (2004) realizou um estudo de mapeamento e zoneamento das áreas com carnaúba em 71 municípios do Piauí, estimando a área de ocorrência dessas palmeiras, que totalizaram $4.023,43 \mathrm{~km}^{2}$ de extensão.

Com vistas a monitorar o desmatamento dos municípios que extraem pó de carnaúba, optou-se por usar o NDVI, que é, consoante Benedetti et al. (2011), o índice mais eficiente para realizar o acompanhamento espectral da vegetação, sobretudo, pela sua disponibilidade de registro diretamente em imagem digital, propiciando inferências sobre as condições da vegetação, em perspectiva sazonal, intertemporal e em diferentes regiões.

O NDVI foi obtido por meio das imagens do satélite Terra, sensor MODIS, produto MOD13Q1 NDVI, disponíveis no site da Embrapa Informática Agropecuária, Laboratório de Geotecnologias. Escolheu-se trabalhar com essas imagens por serem as que melhor se adequam aos objetivos do estudo, tendo em vista que a Embrapa fez um mosaico de imagens de acordo com a divisão política brasileira e os dados estão disponíveis a partir de fevereiro de 2000.

A opção pelo sensor MODIS reside, ainda, no fato de ele possuir resolução espacial maior que outros que produzem o mesmo índice, como o AVHRR e SEVIRI, 
possibilitando maior detalhamento nas imagens. Enquanto a resolução espacial do sensor MODIS é de $250 \mathrm{~m}$, a do AVHRR é de 1,1 km e SEVIRI $3 \mathrm{~km}$. O MOD13Q1 é uma base global de índices de vegetação (NDVI, Enhanced Vegetation Index e Pixel Reliability) com resolução espacial de 250 metros e temporal de 16 dias. O NDVI, em consonância com Huete et al. (2002), é obtido por meio da fórmula 1:

$$
\mathrm{NDVI}=\frac{\rho_{\mathrm{NIR}}-\rho_{\mathrm{red}}}{\rho_{\mathrm{NIR}}+\rho_{\mathrm{red}}}
$$

Em que: $\rho_{\text {NIR }}=$ valor da reflectância na banda do infravermelho próximo;

$\rho_{\text {red }}=$ valor da reflectância na banda do vermelho visível.

O NDVI está compreendido no intervalo [-1; 1]. Melo, Sales e Oliveira (2011) aduziram que água e nuvens apresentam valores negativos; solo exposto, ou com vegetação rala e esparsa, possui valores positivos, mas não muito altos; e vegetação densa e úmida, bem próximos de 1 .

Assim, foram baixadas as imagens MOD13Q1 NDVI para o Piauí e Ceará entre 2000 e 2011. As datas referentes às imagens são 13-29 de setembro em todos os anos. Essas imagens foram recortadas no ArcGIS 10.1, tendo como base a máscara de municípios produtores de pó de carnaúba, e seus pixels foram classificados pela simbologia em cinco intervalos de variação ( $\leq 0$; >0 e $\leq 0,25$; > $0,25$ e $\leq 0,50 ;>0,50$ e $\leq 0,75 ;$ e $>0,75)$. A divisão em cinco classes baseou-se na metodologia adotada por Melo, Sales e Oliveira (2011), com todos os valores negativos em um mesmo nível, e os demais distribuídos em quatro conjuntos.

Quadro 01 - Vegetação predominante, segundo o intervalo de variação do NDVI

\begin{tabular}{|c|c|c|c|c|c|}
\hline $\begin{array}{c}\text { Tipo de } \\
\text { vegetação } \\
\text { predominante }\end{array}$ & $\begin{array}{c}\text { Vegetação } \\
\text { densa }\end{array}$ & $\begin{array}{c}\text { Vegetação } \\
\text { semidensa }\end{array}$ & $\begin{array}{c}\text { Vegetação } \\
\text { rala }\end{array}$ & Solo exposto & $\begin{array}{c}\text { Nuvens, } \\
\text { chuva }\end{array}$ \\
\hline $\begin{array}{c}\text { Intervalo de } \\
\text { variação do } \\
\text { NDVI }\end{array}$ & $>0,75$ & $\begin{array}{c}>0,50 \mathrm{e} \leq \\
0,75\end{array}$ & $\begin{array}{c}>0,25 \mathrm{e} \leq \\
0,50\end{array}$ & $>0 \mathrm{e} \leq 0,25$ & $\leq 0$ \\
\hline
\end{tabular}

Fonte: elaborado pelas autoras, 2017.

Para inspecionar a ocorrência de supressão de vegetação, além dos dados do NDVI, foram coletadas informações sobre precipitação no site do CPTEC/INPE, as quais estão disponíveis para 124 regiões, distribuídas em caixas de $2,5^{\circ} \times 2,5^{\circ}$ de 
latitude e longitude, sobre o país. Os municípios que exploram economicamente a carnaúba localizam-se em oito destas regiões, conforme o Mapa 02.

Mapa 02 - Regiões de monitoramento climático do CPTEC/INPE e áreas dos municípios com exploração econômica de carnaúba
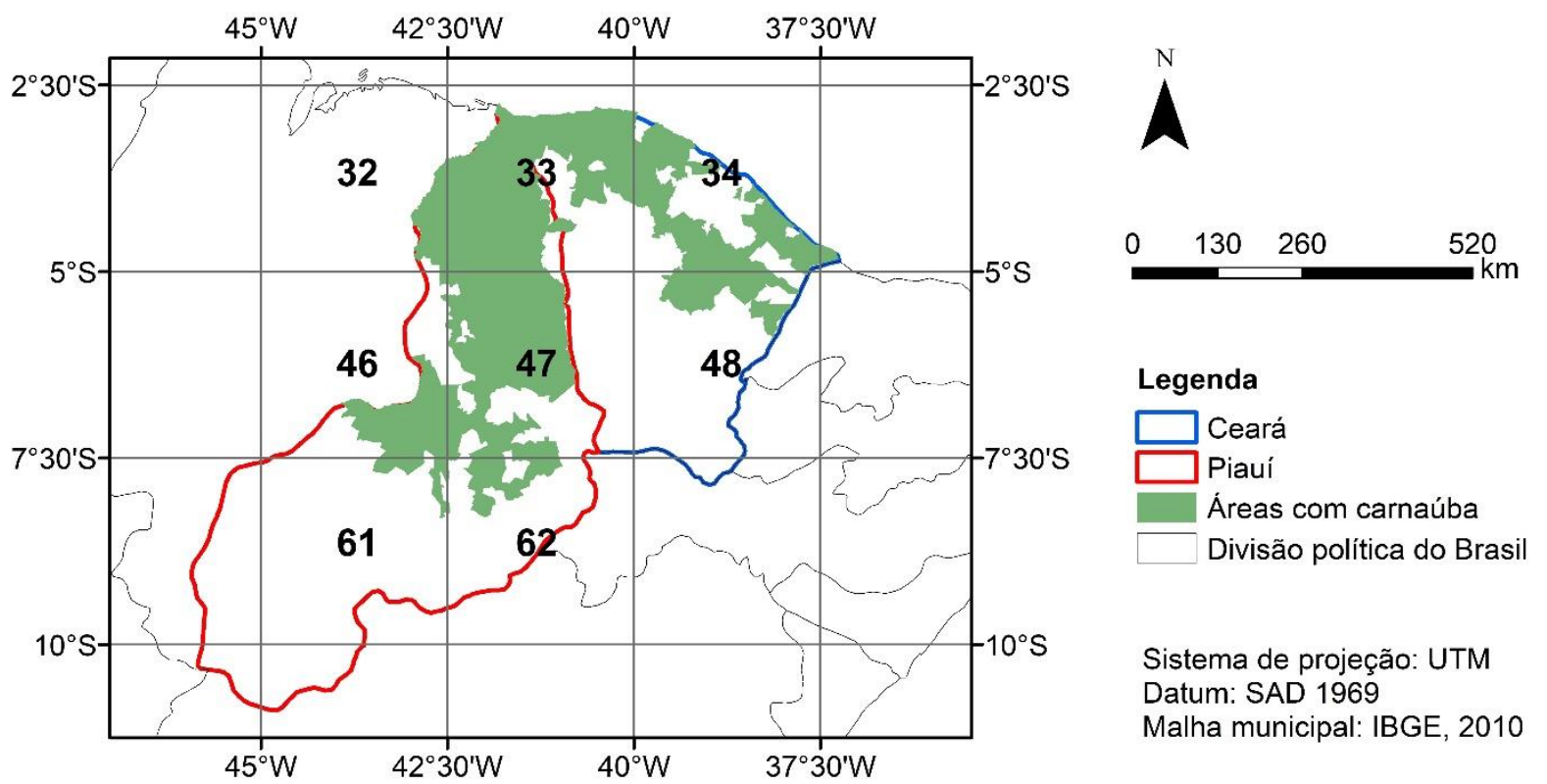

Sistema de projeção: UTM Datum: SAD 1969

Malha municipal: IBGE, 2010

Fonte: Elaboração - Emiliana Barros Cerqueira. Dados básicos INPE.

Pelo Mapa 02, as áreas dos municípios com carnaúba no Piauí e Ceará localizam-se nas regiões 32, 33, 34, 46, 47, 48, 61 e 62 de monitoramento do clima disponibilizadas no INPE. Para cada uma dessas, coletaram-se os dados referentes à precipitação acumulada no ano e sua distribuição. Estes dados foram analisados graficamente. Escolheram-se, então, os anos com quantidade e distribuição de chuvas mais idênticos, em cada região, a fim de estabelecer a comparação do NDVI, representado cartograficamente, e analisar a ocorrência de supressão de vegetação.

As taxas de crescimento demográfico e econômico foram definidas a partir dos dados do IBGE referentes ao PIB, à população rural e urbana, e à área total do município, em 2000 e 2010. Com base nessas informações, calcularam-se a densidade demográfica (total de habitantes por quilometro quadrado) e a taxa de urbanização (percentual da população total que reside na área urbana). A análise dessas características foi efetivada por meio de representação cartográfica.

\section{Desmatamento dos municípios com áreas de carnaubais no Piauí e Ceará}

Inicialmente, investigou-se a evolução do Índice de Vegetação por Diferença Normalizada ao longo dos anos de 2000 a 2011, nos municípios do Piauí e do Ceará 
que realizam extração do pó cerífero de carnaúba, vide Mapa 03.

Mapa 03 - Evolução do Índice de Vegetação por Diferença Normalizada, de 2000 a 2011, dos municípios que exploram o pó de carnaúba no Piauí e Ceará
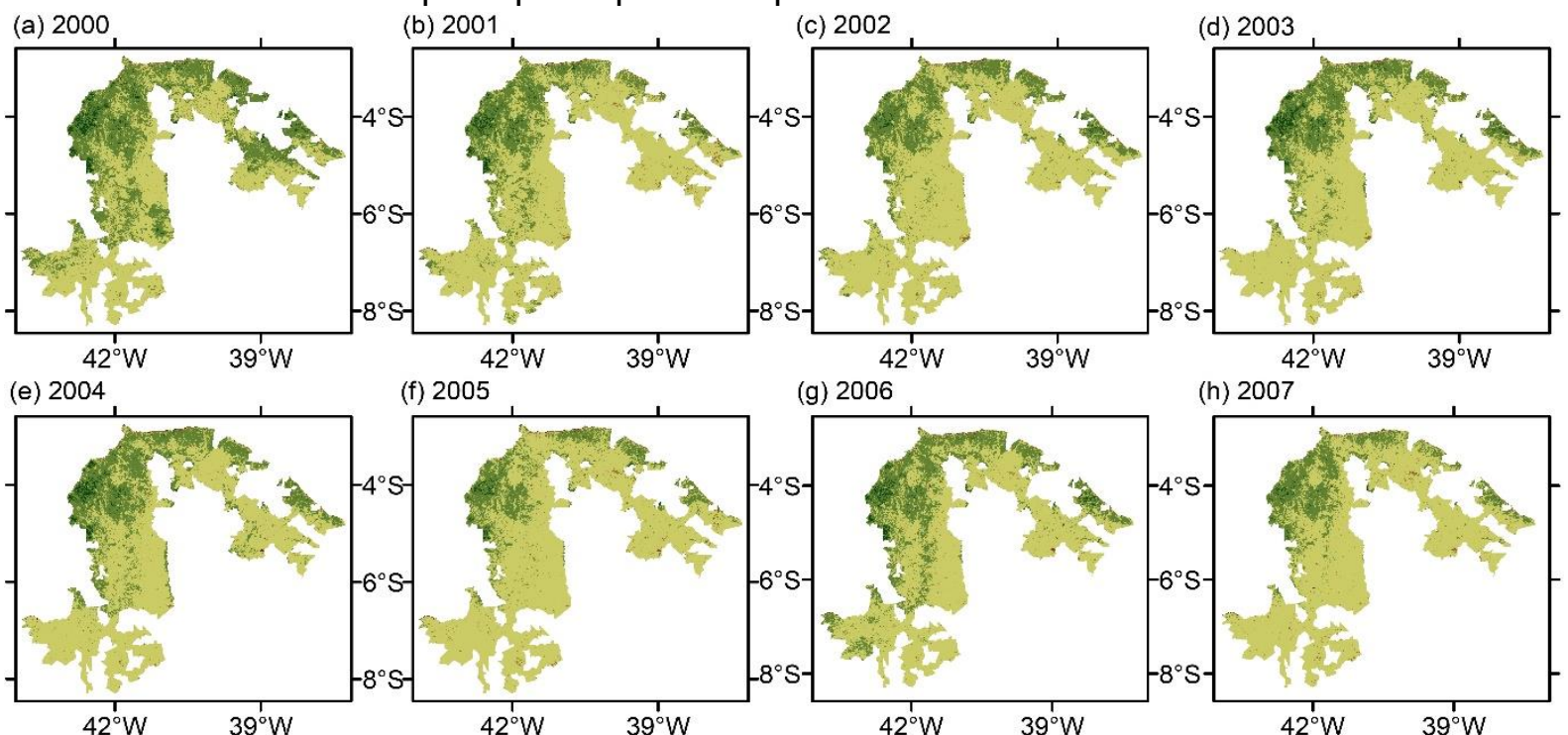

(f) 2005
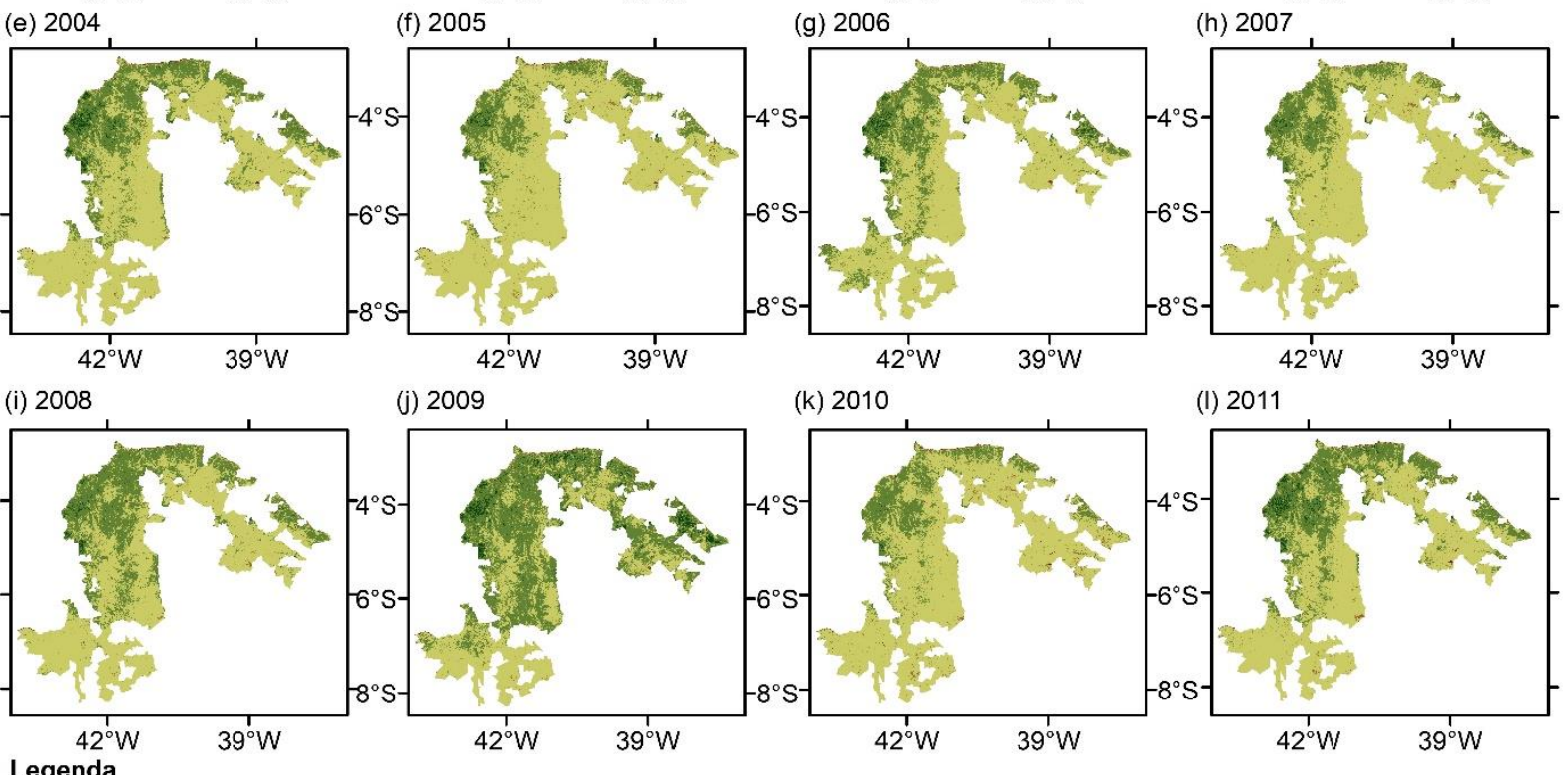

(j) 2009
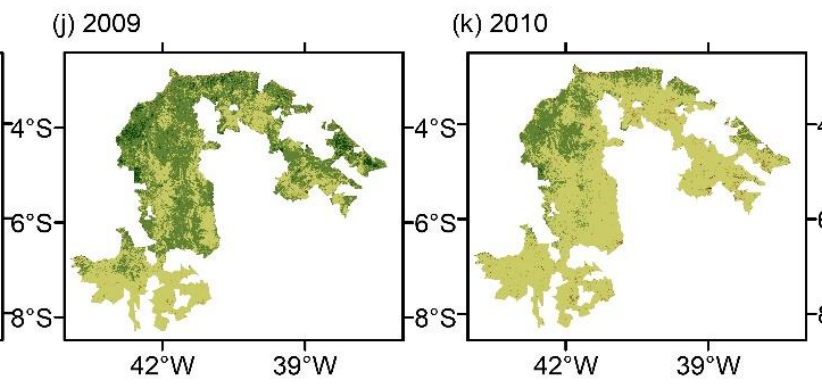

(I) 2011

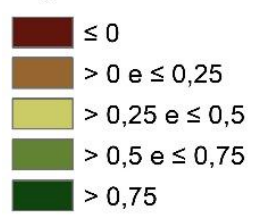

Fonte: Elaboração - Emiliana Barros Cerqueira. Dados básicos: Embrapa.

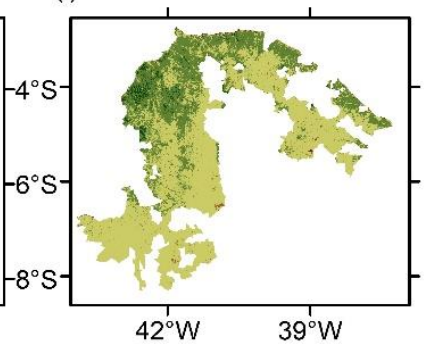

Ao longo do período em análise, predominou, nos dois Estados, o intervalo de variação do NDVI maior que 0,25 e menor ou igual a 0,50 , equivalente à vegetação rala. Esses resultados corroboram o fato de esses municípios estarem inseridos no bioma caatinga (ver Mapa 4). Para Córdula, Queiroz e Alves (2008), este conta com uma vegetação caracterizada por predominância de uma floresta baixa, sendo composta primordialmente por arbustos e árvores pequenas.

Queiroz, Rapini e Giulietti (2006) asseguram que as árvores não chegam a formar um dossel contínuo. O IBGE (2012) qualifica a caatinga do nordeste brasileiro como lenhosa aberta, espinhosa e caducifólica (planta que perde suas folhas em certa estação do ano). 
Mapa 04 - Biomas brasileiros e bioma dos municípios que extraem pó cerífero de carnaúba no Piauí e Ceará

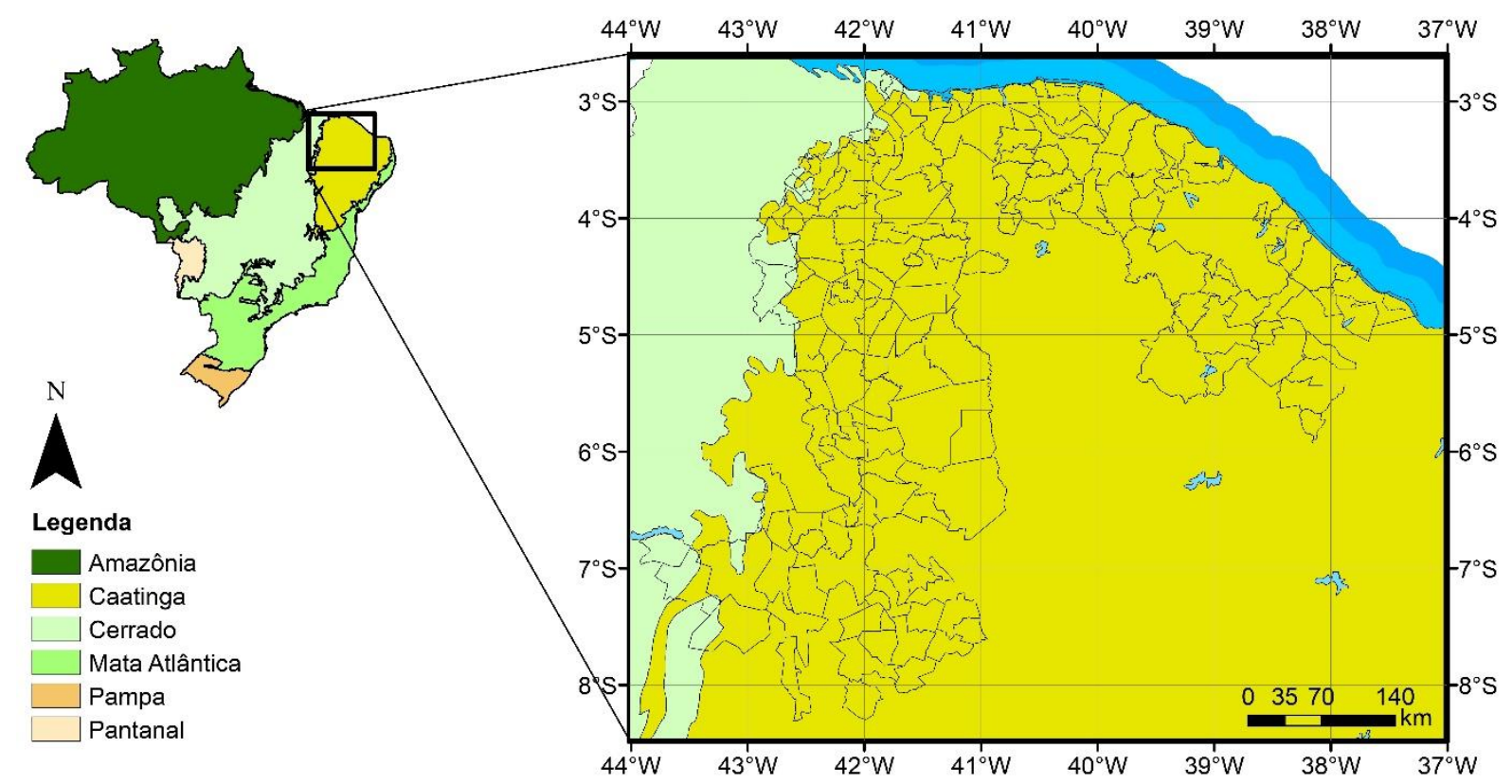

Fonte: Elaboração - Emiliana Barros Cerqueira. Dados básicos IBGE.

O Mapa 04 ilustra que os municípios nos quais existe a atividade de extração de pó de carnaúba estão localizados, quase em sua totalidade, no bioma caatinga. Mantovani (2003) esclareceu que, em concordância com a classificação fitogeográfica da flora, a carnaúba é uma das espécies encontradas na zona dos cocais, caracterizada como uma área de transição entre as florestas amazônica, a savana e a caatinga, onde a vegetação dominante é marcada pela presença de uma ou mais espécies de palmeiras.

Outro aspecto marcante é o fato de o NDVI ser influenciado por variáveis climáticas. Como se convalida no Mapa 3, no ano de 2009 a vegetação semidensa, compreendida no intervalo de 0,50 a 0,75 , sobressaiu-se, porque no período analisado, esse foi o que registrou os maiores valores de precipitação pluviométrica. A evolução do índice em todo o horizonte temporal (2000 - 2011) desvelou comportamento análogo ao nível de chuvas ocorrido durante esses anos.

São vários os trabalhos que associam modificações no NDVI relacionadas à pluviometria, como o de Santos e Shimabukuro (1993), Kazmierczak (1996), Gurgel, Ferreira e Luiz (2003), Braga et al. (2003), Freire e Pacheco (2005), Lucas e Schuler (2007), Lopes et al. (2010). Dessa forma, buscou-se informações sobre precipitação pluviométrica nos municípios estudados. Primeiramente, desnudou-se a quantidade 
de chuvas acumulada em cada ano, como ilustrado no Gráfico 01.

Gráfico 01 - Precipitação acumulada, em mm, entre janeiro e dezembro, de 2000 a 2012, nas regiões 32, 33, 34, 46, 47, 48, 61 e 62

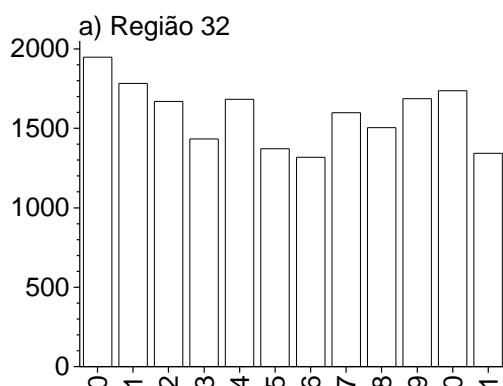

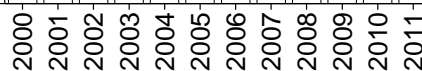

d) Região 46

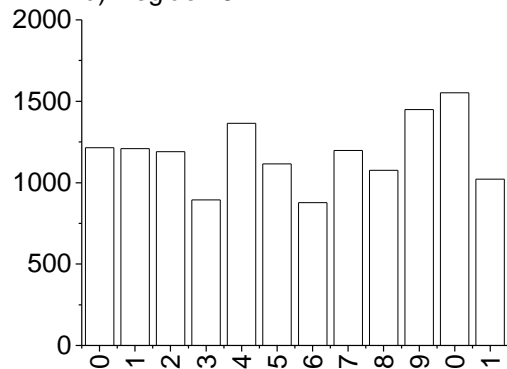

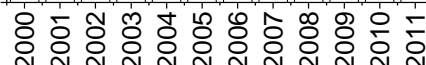

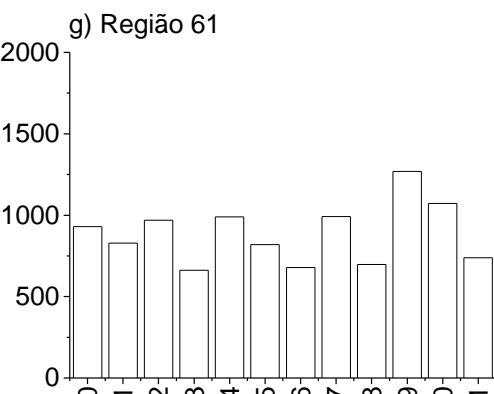

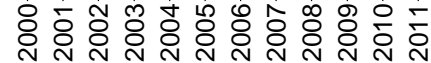

b) Região 33

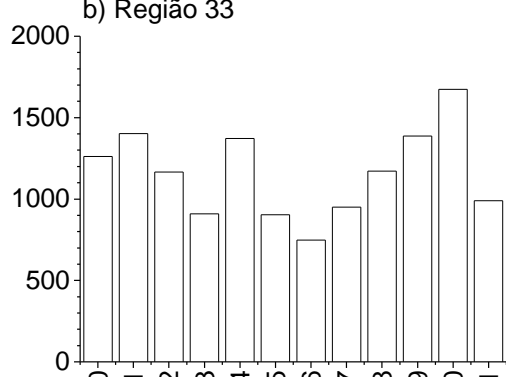

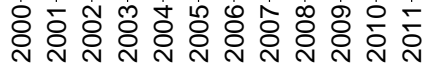
e) Região 47

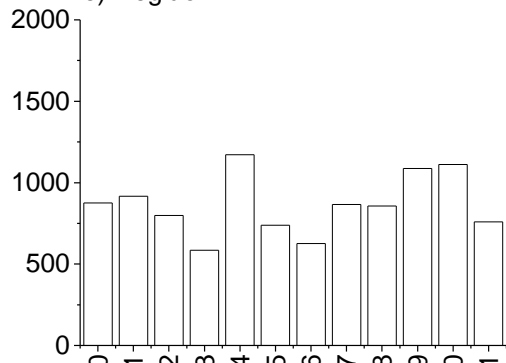

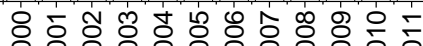

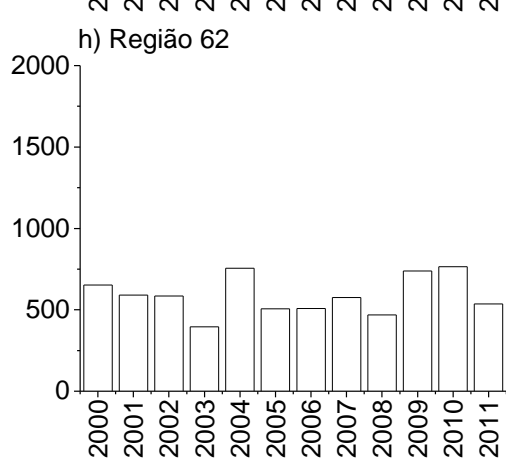

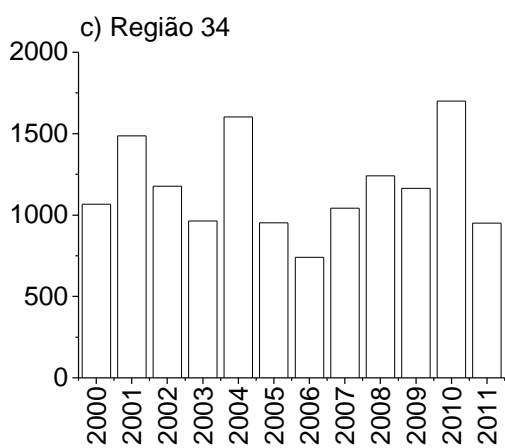

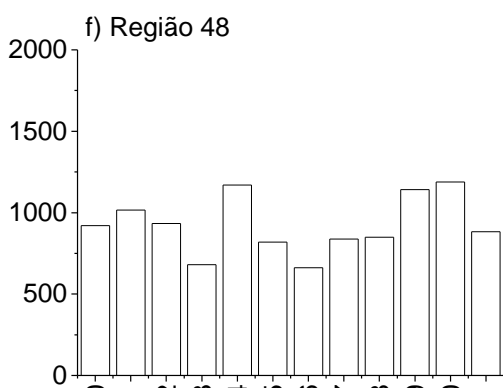

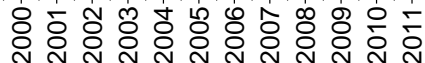

Fonte: Elaboração - Emiliana Barros Cerqueira. Dados básicos: INPE.

Pelo Gráfico 01 foram selecionados os anos mais similares em relação à quantidade de chuvas acumulada em um ano, em cada região, para compará-los quanto à sua distribuição. Os que se mostraram mais semelhantes estão ilustrados no Gráfico 02. 
Gráfico 02 - Distribuição de precipitação nas regiões 32, 33, 34, 46, 47, 48, 61 e 62

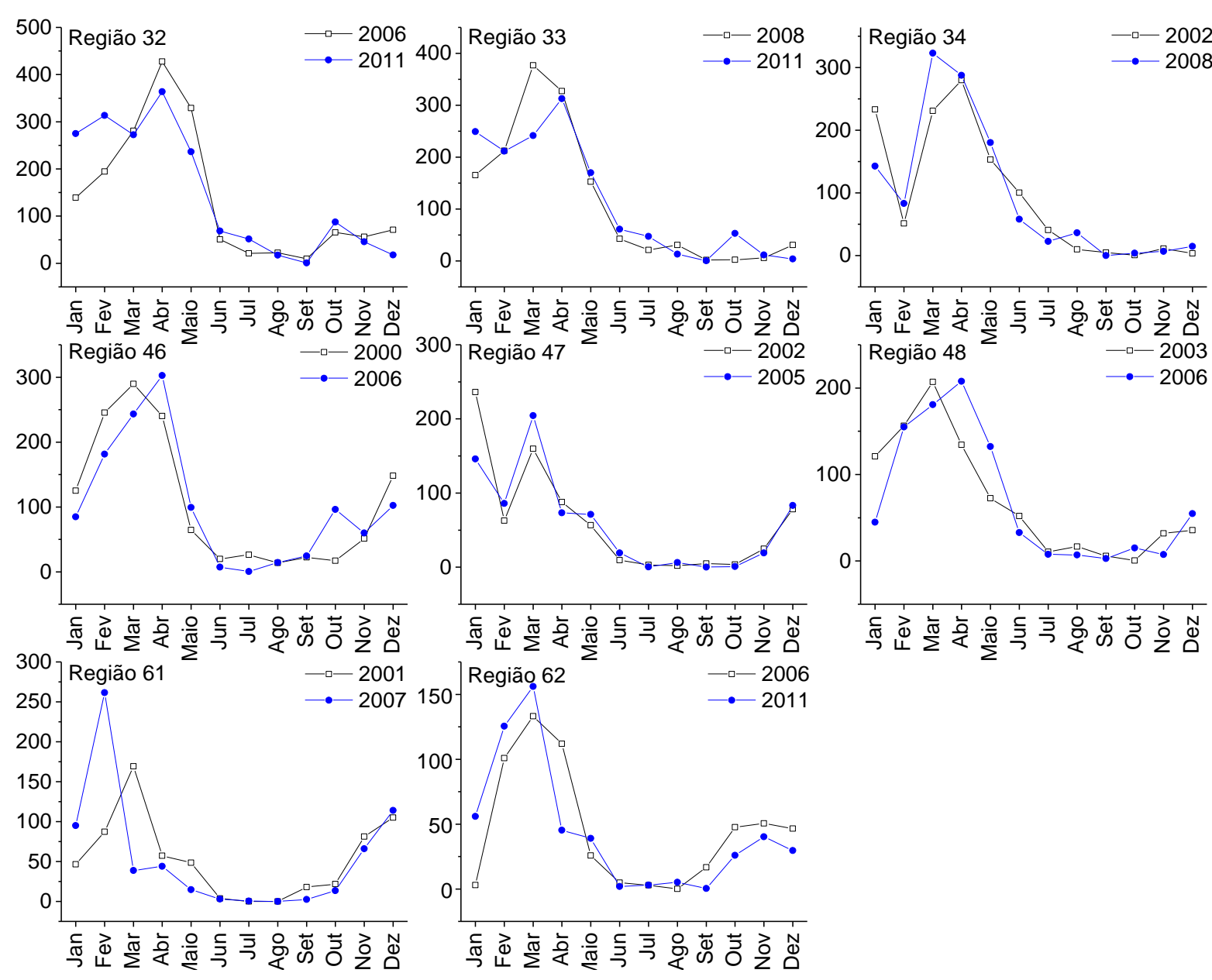

Fonte: Elaboração - Emiliana Barros Cerqueira. Dados básicos: INPE.

Os anos que estão representados, em cada região, no Gráfico 02, foram aqueles separados para fazer a comparação do NDVI. Por exemplo, na região 32, foram confrontadas as imagens do índice referentes aos anos de 2006 e 2011 (ver Mapa 05).

As setas, no Mapa 5, indicam as áreas em que houve alteração na cobertura vegetal. Por meio da plataforma MapBiomas foi possível identificar que esses locais sinalizados representam uma área de transição de cobertura florestal ou áreas naturais não florestais para agropecuária ou áreas não vegetadas.

Considerando que a supressão de vegetação mostrada pelo NDVI no Mapa 05 não teve como fator determinante o índice pluviométrico, estimaram-se variáveis demográficas (taxa de urbanização e densidade demográfica) e econômicas (PIB), tendo em vista que autores como Mueller (2007) ratificam que a escala produtiva da 
economia e o número de habitantes são fatores determinantes para a degradação ambiental. 
Mapa 05 - Índice de Vegetação por Diferença Normalizada das regiões 32, 33, 34, 46, 47, 48, 61 e 62
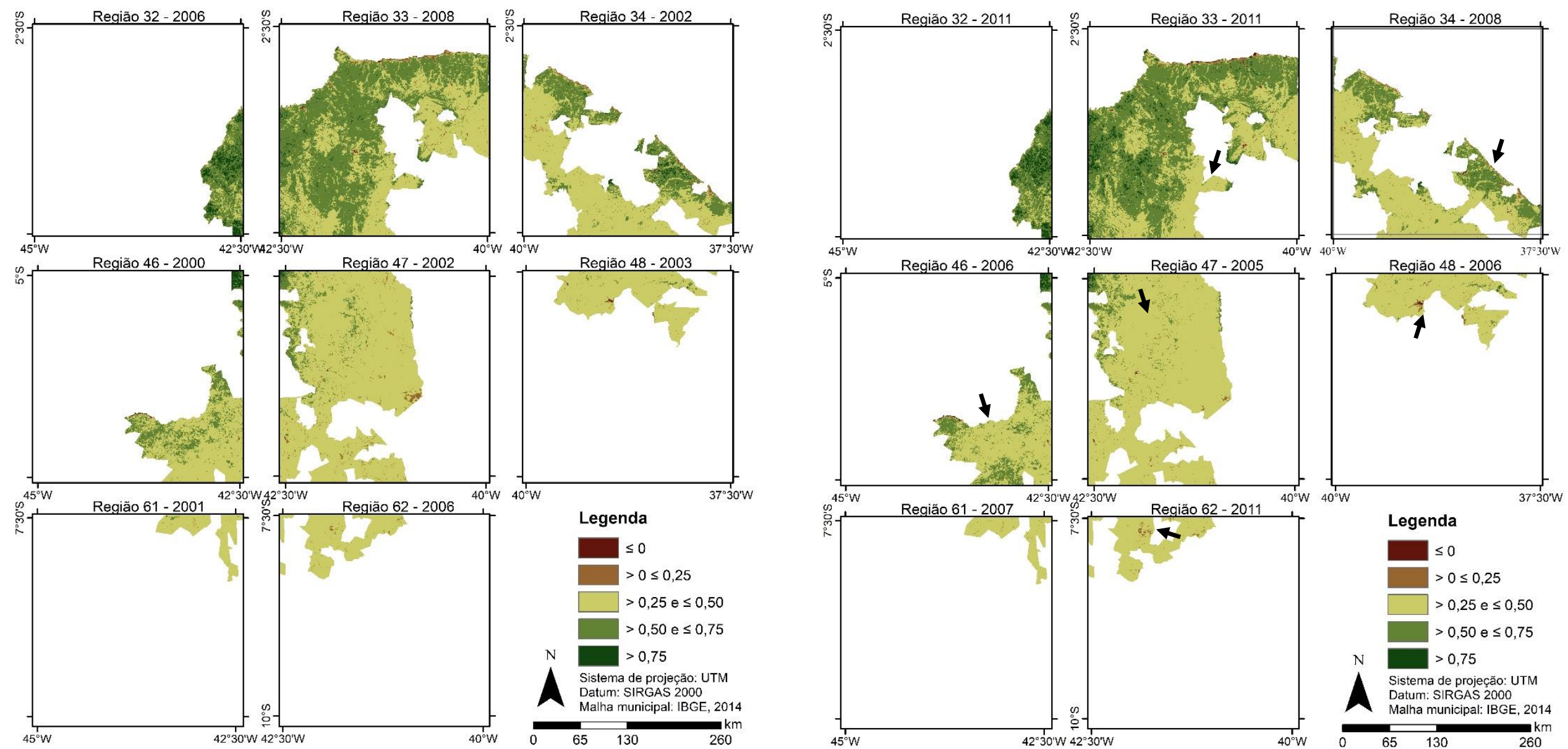

Legenda
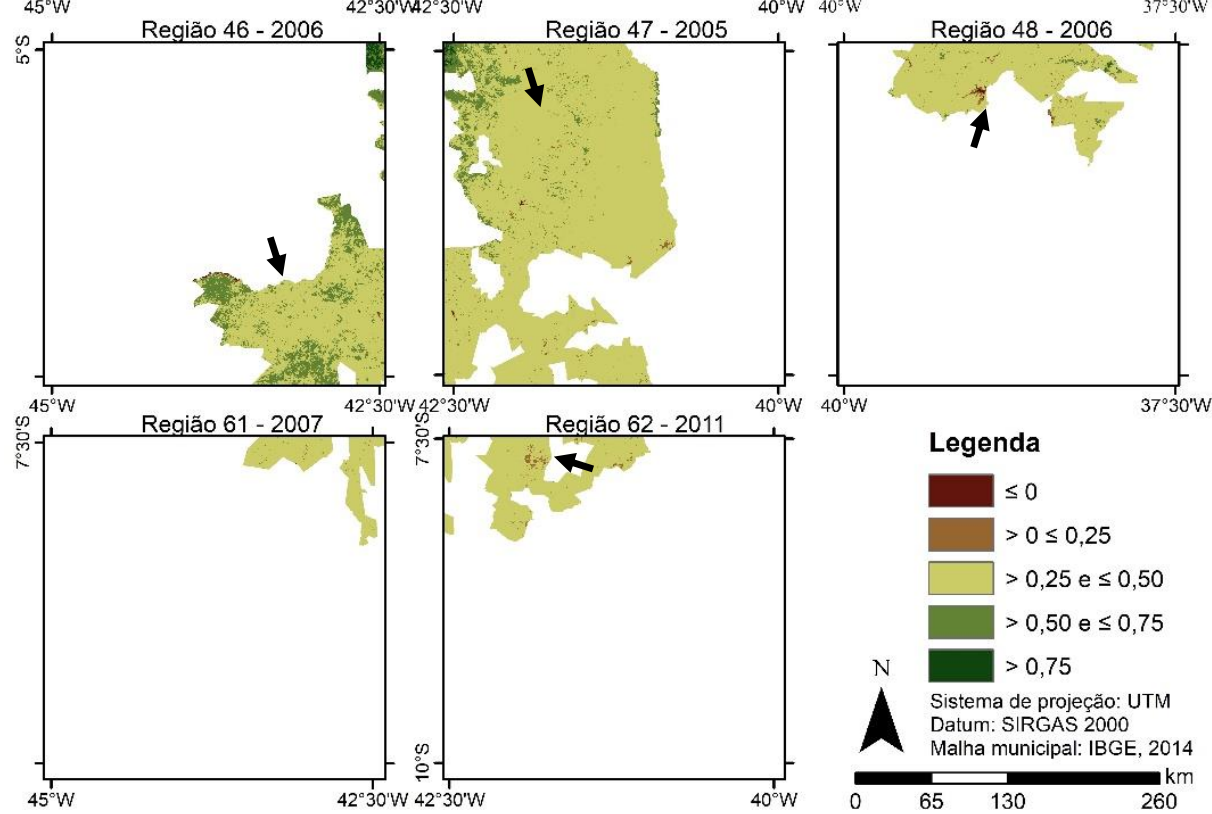

Fonte: Elaboração - Emiliana Barros Cerqueira. Dados básicos Embrapa.
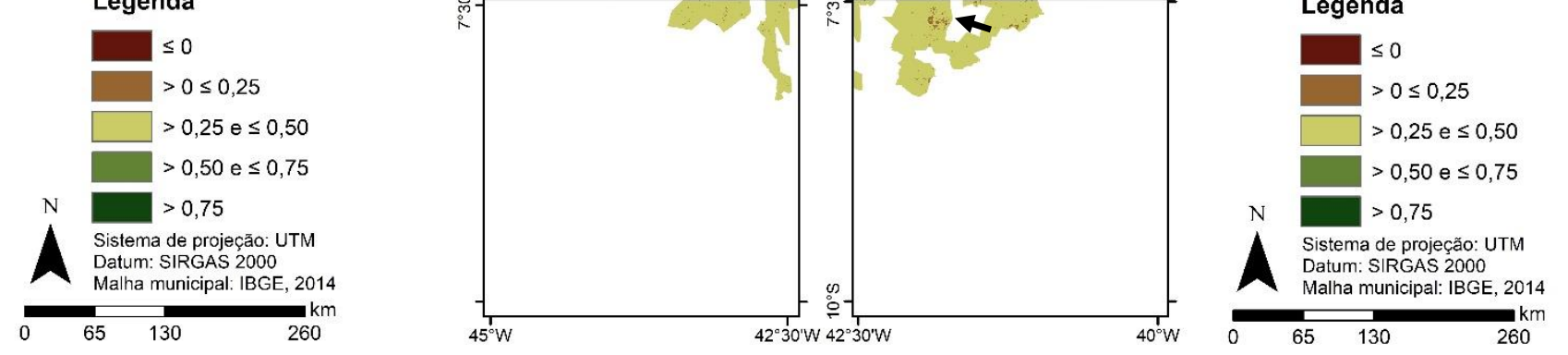
$\mathrm{Na}$ região 33, as principais modificações na cobertura do solo foram notadas no município de Croatá (CE), que elevou sua taxa de urbanização em 16,5\% e o PIB em $277,7 \%$, entre 2000 e 2010. A região 34, externou as diferenças mais notáveis em Cascavel e Beberibe. Cascavel, contou com um aumento de aproximadamente 15,7\% na densidade demográfica entre 2000 e 2010; em Beberibe, o PIB cresceu 341,3\% entre 2000 e 2010. Na região 46, houve supressão de vegetação, nomeadamente em Jerumenha, onde o PIB exibiu uma elevação de 305,7\% entre 2000 e 2010 e em Floriano cresceu 335,8\%.

As diferenças mais perceptíveis na região 47 exprimiram que a supressão ocorreu nos municípios de Castelo do Piauí, onde o PIB cresceu 296,1\% e a taxa de urbanização, 24,2\%, entre 2000 e 2010; Santa Cruz dos Milagres, onde houve aumento de 13,8\% na densidade demográfica; e São João da Serra, cuja taxa de urbanização subiu 18,1\%, entre 2000 e 2010. Na região 48, houve supressão de vegetação em Banabuiú, onde o PIB elevou-se em 262,8\%, entre 2000 e 2010. Na região 62, ocorreu supressão de vegetação, sobretudo em Campinas do Piauí, onde a taxa de urbanização se revelou 11,2\% maior em 2010, em relação a 2000.

Alguns autores relacionaram a degradação ambiental ao processo de urbanização, como Grostein (2001) que assentiu que os processos de expansão e transformação urbana geraram problemas socioambientais relacionados à irracionalidade no uso e na ocupação do solo, alterando o meio ambiente.

Seguindo a mesma linha de raciocínio, Penna (2002) abonou que a expansão das cidades não representa o uso mais apropriado do solo, já que destrói a vegetação, canaliza, assoreia e polui rios, além de contaminar o ar e o solo, e compactar e asfaltar vias, provocando as enchentes. Sem falar da pobreza, violência e marginalidade que acompanham esse processo, trazendo a devastação ambiental e social.

Feitosa et al. (2011) desvendaram que o aumento da temperatura e a redução das áreas verdes foram consequências do crescimento urbano. Cerqueira e Gomes (2017) atribuíram o desmatamento de carnaubais em Campo Maior à expansão de empreendimentos imobiliários.

Rivero et al. (2009) mostraram a relação do desmatamento na Amazônia com o alargamento da atividade econômica, especificamente, da pecuária e da 
agricultura, impulsionadas pelo aumento da demanda nacional e internacional da carne bovina, diretamente, e da soja, indiretamente.

No Mapa 06, é estampada a taxa de crescimento de cada município entre 2000 e 2010, conforme as variáveis socioeconômicas mencionadas: PIB, densidade demográfica e taxa de urbanização.

Mapa 06 - Taxa de crescimento percentual da urbanização, da densidade demográfica e do Produto Interno Bruto entre 2000 e 2010 nos municípios analisados
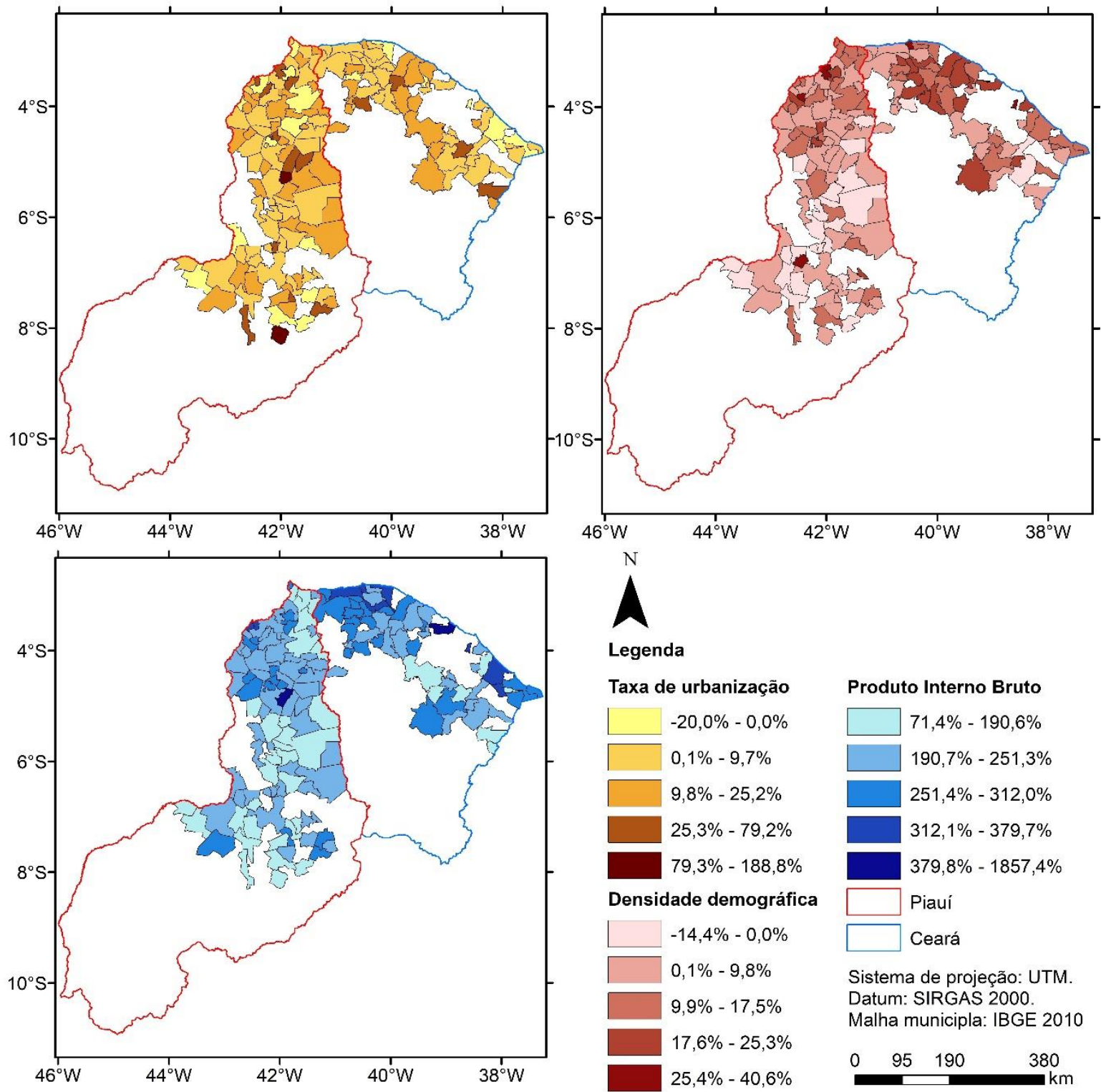

Fonte: Elaboração - Emiliana Barros Cerqueira. Dados básicos: IBGE.

No Mapa 06 é possível notar que das três variáveis analisadas, apenas o PIB apresentou crescimento em todos os municípios. A taxa de urbanização e a densidade demográfica tiveram decréscimo em, respectivamente, 13 e 9 municípios do Piauí, e 13 e 15 do Ceará. 
Os municípios que foram mencionados, a partir da análise do Mapa 5, apresentaram uma ou mais variáveis socioeconômicas altas, dentre as estudadas: PIB, densidade demográfica e taxa de urbanização. No entanto, deve-se ressaltar que os municípios que exibiram as maiores taxas de crescimento de urbanização, densidade demográfica e PIB não foram aqueles onde se notou a supressão de vegetação.

\section{Considerações Finais}

O uso do Índice de Vegetação por Diferença Normalizada quando confrontado de 2000 a 2011, nos municípios em análise, abalizou as mudanças ocorridas na cobertura do solo em decorrência do nível de precipitação, de tal modo que registrou os maiores valores em 2009 exatamente o ano com menor déficit hídrico. Daí a importância de avaliar a quantidade e distribuição de chuva nesses locais, comparando os anos em que a precipitação for análoga.

Por conseguinte, o NDVI mostra eficácia para qualificar a eliminação da cobertura vegetal apenas quando se levam em consideração imagens cujas datas apresentem similaridades pluviométricas, tanto a acumulada durante $\mathrm{o}$ ano quanto a que ocorreu em cada mês.

A pesquisa sobre a cobertura vegetacional nos municípios que extraem pó de carnaúba no Piauí e Ceará revelou que em alguns deles houve remoção de vegetação. Nessas localidades, também se verificou aumento relativo nas taxas de crescimento da urbanização, da densidade demográfica e do PIB, entre 2000 e 2010, explicitando essa supressão, já que a quantidade de habitantes em dado local e a forma como eles se distribuem e exploram seus recursos constituem fatores decisivos para a degradação ambiental.

Seguindo essa metodologia, constatou-se que houve supressão de vegetação florestal ou de áreas naturais não florestais para dar lugar a agropecuária ou áreas não vegetadas nos seguintes municípios piauienses Campinas do Piauí, Castelo do Piauí, Floriano, Jerumenha, Santa Cruz dos Milagres, São João da Serra; e cearenses Cascavel, Croatá, Banabuiú e Beberibe. Nesses locais, foi possível observar a elevação de pelo menos uma das três variáveis socioeconômicas estudadas (PIB, densidade demográfica e taxa de urbanização).

Por fim, ressalta-se a importância de monitorar essas áreas para estabelecer 
políticas públicas adequadas para a conservação do meio ambiente. Cabe advertir, ainda, que o estudo se limitou à identificação de supressão ou não da vegetação de modo geral, não especificando se as áreas desmatadas foram as de carnaubais.

\section{REFERÊNCIAS}

ANDRADE, K. de S.; FEITOSA, P. H. C.; BARBOSA, M. P. Sensoriamento remoto e sig na identificação de áreas em processo de desertificação no município de Serra Branca - PB: estudo de caso. In: SIMPÓSIO BRASILEIRO DE SENSORIAMENTO REMOTO, 13., 2007. Anais... Florianópolis, 2007, p. 4351-4356.

AQUINO, C. M. S.; OLIVEIRA, J. G. B. Estudo da dinâmica do Índice de Vegetação por Diferença Normalizada (NDVI) no núcleo de São Raimundo Nonato-PI. GEOUSP - Espaço e Tempo, São Paulo, n. 31, p. 157-168, 2012.

BENEDETTI, A. C. P. et al. Índice de vegetação por diferença normalizada (NDVI) do sensor Modis: aplicações para estudos de uso e cobertura da terra na metade sul do Rio Grande do Sul. In: SIMPÓSIO BRASILEIRO DE SENSORIAMENTO REMOTO, 15., 2011. Anais... Curitiba, INPE, 2011, p. 6144-6152.

BRAGA, C. C.; BRITO, J. I. B.; SANSIGOLO, C. A.; RAO, T. V. R. Tempo de resposta da vegetação às variações sazonais da precipitação no Nordeste do Brasil. Revista Brasileira de Agrometeorologia, Santa Maria, v. 11, p. 149-157, 2003.

CARDOZO, F. da S. et al. Avaliação de áreas queimadas a partir dos índices espectrais NDVI e NDBR. SIMPÓSIO BRASILEIRO DE SENSORIAMENTO REMOTO, 15. 2011, Curitiba. Anais... Curitiba: INPE, 2011, p. 7950-7957.

CERQUEIRA, E. B.; GOMES, J. M. A.; SILVA, M. S. da. Política de Garantia de Preços Mínimos e preservação na cadeia produtiva da cera de carnaúba. Informe Gepec, Toledo, v. 15, n. 1, p. 64-81, jan./jun. 2011.

CERQUEIRA, E. B.; GOMES, J. M. A. Desmatamento da carnaúba (Copernicia prunifera (Mill.) H.E. Moore) em Campo Maior-PI. Geotextos, Salvador, v. 13, n. 2, p. 161-181, dez. 2017.

CÓRDULA, E.; QUEIROZ, L. P. de; ALVES, M. Checklist da flora de mirandiba, Pernambuco: leguminosae. Rodriguésia. Rio de Janeiro, v. 59, n. 3, p. 597-602. 2008.

D'ALVA, O. A. O extrativismo da carnaúba no Ceará. Fortaleza: BNB, 2007 (Série BNB Teses e Dissertações, v. 4).

DUAN, $\mathrm{H}$. et al. Assessing vegetation dynamics in the Three-North Shelter Forest region of China using AVHRR NDVI data. Environ Earth Sci. Vol. 64, p. 1011-1020, 2011.

FEITOSA, S. M. R. et al. Consequências da urbanização na vegetação e na temperatura da superfície de Teresina - Piauí. REVSBAU, Piracicaba, v.6, n.2, p.58-75, 2011.

FREIRE, N. C. F.; PACHECO, A. P. Aspectos da detecção de áreas de risco a desertificação na região de Xingo. In: SIMPÓSIO BRASILEIRO DE SENSORIAMENTO REMOTO, 12. Goiânia. Anais... Goiânia, 2005, p. 525-532. 
GURGEL, H. C.; FERREIRA, N. J.; LUIZ, A. J. B. Estudo da variabilidade do NDVI sobre o Brasil, utilizando-se a análise de agrupamentos. Revista Brasileira de Engenharia Agrícola e Ambiental, Campina Grande, v. 7, n. 1, p. 85-90, 2003.

GROSTEIN, M. D. Metrópole e expansão urbana a persistência de processos “insustentáveis". São Paulo em Perspectiva, São Paulo, v. 15, n. 1, p. 13-19, 2001.

HONG, W. Y. et al. The spatial and temporal correlation analysis between MODIS NDVI and SWAT predicted soil moisture during forest NDVI increasing and decreasing periods. Journal of Civil Engineering, Coreia, v. 14, n. 6, p. 931-939, 2010.

HUETE, A. R. et al. Overview of radiometrics and biophysical performance of the MODIS vegetation index. Remote Sensing of Environment, Nova York, v. 83, p. 195-213, 2002.

IBGE - INSTITUTO BRASILEIRO DE GEOGRAFIA E ESTATÍSTICA. Censo Agropecuário. Rio de Janeiro: IBGE, 2000. Disponível em: <http:// www.sidra.ibge.gov.br>. Acesso em: 31 out. 2017.

IBGE - INSTITUTO BRASILEIRO DE GEOGRAFIA E ESTATÍSTICA. Censo Agropecuário. Rio de Janeiro: IBGE, 2010. Disponível em: <http:// www.sidra.ibge.gov.br>. Acesso em: 31 out. 2017.

IBGE - INSTITUTO BRASILEIRO DE GEOGRAFIA E ESTATÍSTICA. Manual Técnico da Vegetação Brasileira. Rio de Janeiro: IBGE, 2012. Disponível em: < https://biblioteca.ibge.gov.br/visualizacao/livros/liv63011.pdf>. Acesso em: 28 fev. 2018.

IBGE - INSTITUTO BRASILEIRO DE GEOGRAFIA E ESTATÍSTICA. Produção da Extração Vegetal e da Silvicultura. Rio de Janeiro: IBGE, 2011. Disponível em: < http://www.inmet.gov.br>. Acesso em: 5 jan. 2018.

INPE - INSTITUTO NACIONAL DE PESQUISAS ESPACIAIS. Índice de vegetação. Divisão de Satélites e Sistemas Ambientais. Disponível em:

<http://webaula.cptec.inpe.br/ndvi/faq.jsp>. Acesso em: 05 dez. 2017.

JORDAN, C. F. Derivation of leaf area index from quality of light on the Forest floor.

Ecology, v. 50, p. 663-666, 1960.

JUNGES, A. H.; FONTANA, D. C. Desenvolvimento de culturas de cereais de inverno no Rio Grande do Sul por meio de perfis temporais do Índice de Vegetação por Diferença Normalizada. Ciência Rural, Santa Maria, v. 39, n. 5, p.1349-1355, 2009.

KAZMIERCZAK, M. L. Uso de dados AVHRR/NOAA GAC para análise da sazonalidade da caatinga. In: SIMPÓSIO BRASILEIRO DE SENSORIAMENTO REMOTO, 8. Salvador.

Anais... Salvador, INPE, 1996, p. 513-518.

LI, S., et al. Identifying spatial patterns of synchronization between NDVI and climatic determinants using joint recurrence plots. Environ Earth Sci. Vol. 64, p. 851-859, 2011.

LOPES, K. L. et al. Parâmetros biofísicos na detecção de mudanças na cobertura e uso do solo em bacias hidrográficas. Revista Brasileira de Engenharia Agrícola e Ambiental, Campina Grande, v. 14, n. 11, p. 1210-1219, 2010.

LUCAS, A. de A.; SCHULER, C. A. B. Análise do NDVI/NOAA em cana-de-açúcar e Mata 
Atlântica no litoral norte de Pernambuco, Brasil. Revista Brasileira de Engenharia

Agrícola e Ambiental, Campina Grande, v. 11, n. 6, p. 607-614, 2007.

MANTOVANI, W. A degradação dos biomas brasileiros. In: RIBEIRO, W. C. (Org.).

Patrimônio Ambiental Brasileiro. São Paulo: Editora da Universidade de São Paulo, 2003. (Uspiana - Brasil 500 Anos). p. 367-442.

MELO, E. T.; SALES, M. C. L.; OLIVEIRA, J. G. B. de. Aplicação do Índice de Vegetação por Diferença Normalizada (NDVI) para análise da degradação ambiental da microbacia hidrográfica Riacho dos Cavalos, Crateús - CE. Ra'e Ga - o Espaço Geográfico em Análise, Curitiba, v. 23, p. 520-533, 2011.

MMA - MINISTÉRIO DO MEIO AMBIENTE. Caatinga. Disponível em: <https://www.mma.gov.br/biomas/caatinga>. Acesso em: 31 out. 2017.

MUELLER, C. Os economistas e as relações entre o sistema econômico e o meio ambiente. Brasília: Unb, 2007.

OLIVEIRA, L. D. de. Os "Limites do Crescimento" 40 anos depois: das "Profecias do Apocalipse Ambiental" ao "Futuro Comum Ecologicamente Sustentável". Revista Continentes, Rio de Janeiro, v. 1, n. 1, p. 72-96, 2012.

PENNA, N. A. Urbanização, cidade e meio ambiente. GEOUSP - Espaço e Tempo, São Paulo, n. 12, pp. 125 - 140, 2002.

MAPBIOMAS - PROJETO MapBiomas - Coleção 4.0 da Série Anual de Mapas de Cobertura e Uso de Solo do Brasil, Disponível em:

<http://plataforma.mapbiomas.org/map\#transitions>. Acesso em: 29 jan. 2020.

QUEIROZ, L. P. de; RAPINI, A.; GIULIETTI, A. M. Rumo ao Amplo

Conhecimento da Biodiversidade do Semi-árido Brasileiro. Brasília: MCT, 2006.

REIS FILHO, A. A. dos (Coord.). Projeto CARNAUPI: mapeamento espacial e zoneamento da carnaúba no Piauí. Relatório, 2004.

RIVERO, S. et al. Pecuária e desmatamento: uma análise das principais causas diretas do desmatamento na Amazônia. Nova Economia, Belo Horizonte, v. 19, n. 1, p. 41-66, 2009.

ROUSE, J.W. et al. Monitoring vegetation systems in the great plains with ERTS. In: EARTH RESOURCES TECHNOLOGY SATELLITE, 1. SYMPOSIUM, 1974, Washington.

Proceedings... Washington: [s.n.], 1974, v.1, sec. A, p. 309-317.

SANTOS, J. R.; SHIMABUKURO, Y. E. O sensoriamento remoto como indicador das fenofases dos cerrados brasileiros: Estudo de caso com dados AVHRR-NOAA. In: SIMPÓSIO BRASILEIRO DE SENSORIAMENTO REMOTO, 7. Curitiba, 1993. Anais... São José dos Campos, INPE, 1993, p.249-257.

SECEX - SECRETARIA DE COMÉRCIO EXTERIOR. Banco de dados do Ministério da Indústria e Comércio Exterior. Exportação de ceras. 2011.

YOUNG, C. E. F. Economia do Extrativismo em Áreas de Mata Atlântica. SIMÕES, L. L., LINO, C. F. (Org.). Sustentável Mata Atlântica: a exploração de seus recursos florestais. $2^{\underline{a}}$ ed. atual. São Paulo: Editora Senac São Paulo, 2003. p. 171-181. 
ZHAOPING, Y. et al. Spatio-temporal changes of NDVI and its relation with climatic variables in the source regions of the Yangtze and Yellow rivers. Journal of Geographical Sciences. v. 21 , n. 6 , p. $979-993,2011$.

\section{NOTAS DE AUTOR}

\section{CONTRIBUIÇÃO DE AUTORIA}

Emiliana Barros Cerqueira - Concepção e elaboração do manuscrito. Coleta de dados. Análise de dados. Elaboração de mapas e gráficos. Revisão da versão final do trabalho.

Jaíra Maria Alcobaça Gomes - Concepção. Participação ativa da discussão dos resultados. Revisão e aprovação da versão final do trabalho.

\section{FINANCIAMENTO}

Bolsa da Coordenação de Aperfeiçoamento de Pessoal de Nível Superior - CAPES.

\section{CONSENTIMENTO DE USO DE IMAGEM}

Não se aplica.

\section{APROVAÇÃO DE COMITÊ DE ÉTICA EM PESQUISA}

Não se aplica.

\section{CONFLITO DE INTERESSES}

Não há conflito.

\section{LICENÇA DE USO}

Este artigo está licenciado sob a Licença Creative Commons CC-BY. Com essa licença você pode compartilhar, adaptar, criar para qualquer fim, desde que atribua a autoria da obra.

\section{HISTÓRICO}

Recebido em: 12-04-2018

Aprovado em: 20-05-2020 